Cooke, W. T., Elkes, J. J., Frazer, A. C., Parkes, J., Peeney, A. L. P., Sammons, H. G. \& Thomas, G. (1946). Quart. F. Med. 15, 141.

Cooke, W. T., Peeney, A. L. P. \& Hawkins, C. F. (1953). Quart. F. Med. 22, 59.

Dicke, W. K. (1950). Coeliakie. M.D. 'Thesis, University of Utrecht.

Dicke, W. K., Weijers, H. A. \& van de Kamer, J. H. (1953). Acta paediat., Stockh., 42, 34.

Findlay, G. M. (1949). (Personal communication.)

Frazer, A. C. \& Sammons, H. G. (1945). Biochem. 7. 39, 122.

French, J. M. (1949). The influence of dietary triglycerides and fatty acids on intestinal absorption, with special reference to the products of rancidity. Ph.D. 'Thesis, University of Birmingham.

Goiffon, R. (1949). Manuel de Coprologie Clinique. Paris: Masson.

Hawes, R. B. (1952). (Personal communication.)

Manson, P. (1880). Med. Rep., Shanghai, p. I9.

McIver, C. (1952). Lancet, 263, 1112.

Ruffin, J. M., Carter, D. D., Johnston, D. H. \& Baylin, G. J. (1954). New Engl. F. Med. 250, 28 r. Sheldon, W. \& Lawson, D. (1952). Lancet, 263, 902.

Taylor, W. H. (1954). Clin. Sci. 13, 239.

Thompson, M. D. (1948). The intraluminar phase of fat absorption in man. M.D. Thesis, University of Birmingham.

van de Kamer, J. H., Huinink, H. ten B., \& Weyers, H. A. (1949). F. biol. Chem. r77, 347.

Weijers, H. A. \& van de Kamer, J. H. (1950). Publ. cent. Inst. Voedingsonderz., T.N.O., Utrecht, no. I 13.

Weijers, H. A. \& van de Kamer, J. H. (r953). Acta paediat., Stockh., 42, 24.

Whipple, D. V. (1936). F. Pediat. 8, 734.

Wollaeger, E. E. \& Scribner, B. H. (1951). Gastroenterology, 19, 224.

\title{
The Absorption of Vitamins in Disorders of the Alimentary Tract
}

\author{
By R. H. GiRdwood, Department of Medicine, University of Edinburgh
}

Space does not permit me to deal with the physiology of absorption of vitamins, but $I$ feel that I should make some reference to the action of intestinal bacteria.

\section{The action of intestinal bacteria}

It has been shown that bacteria similar to those present in the alimentary tract, when grown under suitable conditions, can synthesize thiamine, riboflavin, nicotinic acid, pantothenic acid, biotin, $p$-aminobenzoic acid, vitamin $B_{12}$ and vitamin K. By means of depleting organisms such as Staphylococcus aureus and Bacterium coli of folic acid and growing them under very strict cultural conditions, Lascelles \& Woods (1952) have induced them to synthesize folic acid. However, other organisms in culture can destroy or absorb vitamins. Table I summarizes an experiment in which the mixed flora from human gastric contents was incubated for $4^{8 \mathrm{~h}}$ in two media with added cyanocobalamin*. Thereafter the amount of vitamin $\mathrm{B}_{12} *$ present was measured microbiologically with Lactobacillus leichmannii as the test organism. The two media used were nutrient broth and the medium of Burkholder ( 1952 ) which contains only dextrose and asparagine together with salts of potassium, sodium, magnesium and ammonia.

* Throughout this paper the terms cyanocobalamin and pteroylglutamic acid are used to denote the pure chemical substances as employed in therapy. The terms vitamin $B_{12}$ and folic acid refer to the substances present in natural materials; they are not necessarily precisely the same chemical substances. 
It will be seen from Table $I$, that under these conditions most of the organisms investigated could absorb cyanocobalamin and that the extent of this uptake differed with the two media employed.

Table I Results of experiments to establish whether mixed flora from human gastric juice removes added cyanocobalamin from culture media

\begin{tabular}{|c|c|c|c|c|c|}
\hline \multirow[b]{3}{*}{$\begin{array}{l}\text { Case } \\
\text { no. }\end{array}$} & \multirow[b]{3}{*}{$\begin{array}{l}\text { Organisms } \\
\text { identified }\end{array}$} & \multicolumn{4}{|c|}{ Content of vitamin $B_{12}$ in } \\
\hline & & \multicolumn{2}{|c|}{ Nutrient broth } & \multicolumn{2}{|c|}{ Burkholder's medium } \\
\hline & & $\begin{array}{l}\text { Before } \\
\text { incubation } \\
(m \mu g / m l .)\end{array}$ & $\begin{array}{c}\text { After } \\
\text { incubation } \\
(\mathrm{m} \mu \mathrm{g} / \mathrm{ml})\end{array}$ & $\begin{array}{l}\text { Before } \\
\text { incubation } \\
(\mathrm{m} \mu \mathrm{g} / \mathrm{ml} \text {.) }\end{array}$ & $\begin{array}{c}\text { After } \\
\text { incubation } \\
(\mathrm{m} \mu \mathrm{g} / \mathrm{ml})\end{array}$ \\
\hline $\mathbf{I}$ & Bacterium coli intermediate Type II & I 30 & 8 & 32 & 24 \\
\hline 2 & Bact, coli Type I & 36 & 12 & 33 & I 5 \\
\hline 3 & $\begin{array}{l}\text { Bacterium aerogenes Type I } \\
\text { Staphylococci }\end{array}$ & 32 & 2 & 29 & 30 \\
\hline 4 & $\begin{array}{l}\text { Bact. coli intermediate Type II } \\
\text { Yeasts }\end{array}$ & 30 & 4 & 30 & I4 \\
\hline 5 & $\begin{array}{l}\text { Bact. aerogenes Type I } \\
\text { Staphylococci } \\
\text { Streptococci }\end{array}$ & 35 & 0.4 & 30 & I 5 \\
\hline 6 & $\begin{array}{l}\text { Bact. coli-mutabile } \\
\text { Staphylococci }\end{array}$ & 29 & 3 & 29 & 22 \\
\hline 7 & Staphylococci & 32 & 32 & 28 & 28 \\
\hline 8 & $\begin{array}{l}\text { Bact. coli Type I } \\
\text { Staphylococci }\end{array}$ & 32 & Trace & 28 & I4 \\
\hline 9 & $\begin{array}{l}\text { Staphylococci } \\
\text { Streptococci }\end{array}$ & $3 \mathrm{I}$ & 25 & 29 & 28 \\
\hline 10 & $\begin{array}{l}\text { Bacterium cloacae } \\
\text { Staphylococci } \\
\text { Streptococci }\end{array}$ & 32 & $\mathbf{I}$ & 32 & 3 \\
\hline I I & $\begin{array}{l}\text { Bact. coli intermediate Type I } \\
\text { Staphylococci } \\
\text { Diphtheroids }\end{array}$ & 28 & I & 32 & 2 \\
\hline
\end{tabular}

The difficulty that arises in attempting to decide about the importance of any such test-tube observations is that our knowledge of the bacterial content of the small intestine is very limited. Bean \& Spies (1940) suggested that vitamin deficiencies might develop in diarrhoeal states because alterations in intestinal flora would interfere with the synthesis of vitamins by bacteria. Many workers have considered the importance of intestinal bacteria in relation to vitamin-deficiency states, including the megaloblastic anaemias, but most of those who have studied the bacteriology of the alimentary tract have examined the gastric and duodenal contents and the faeces, and from their results have made surmises about the bacteriology of the small intestine. It is very difficult to carry out intubation experiments which do not involve contamination of one level of the alimentary tract with the contents of another; experiments based on sterilization with antibiotics are too indirect to be satisfactory.

The Australian workers Cregan \& Hayward (1953), and later Cregan, Dunlop \& Hayward (1953), have published the results of observations involving the culturing of organisms obtained at operation by inserting needles directly through the wall of the small intestine. Only a transient flora was found in normal persons, 


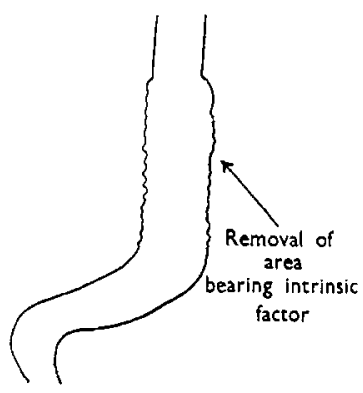

$a$

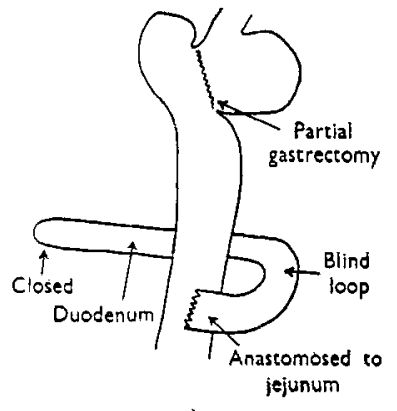

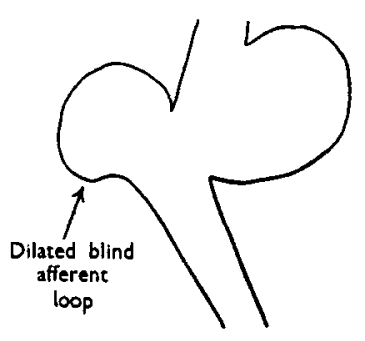

b

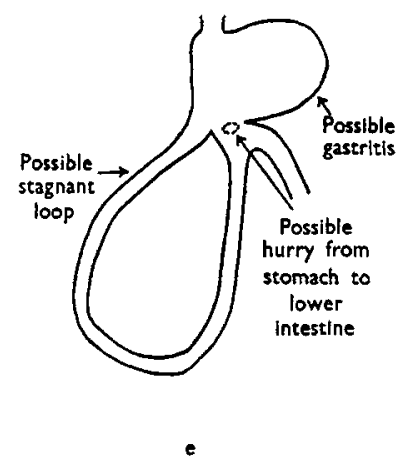

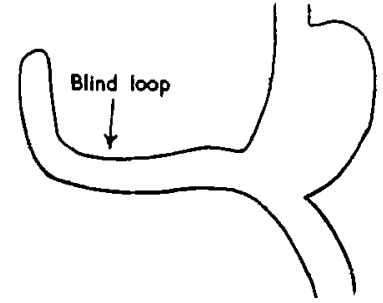

$c$

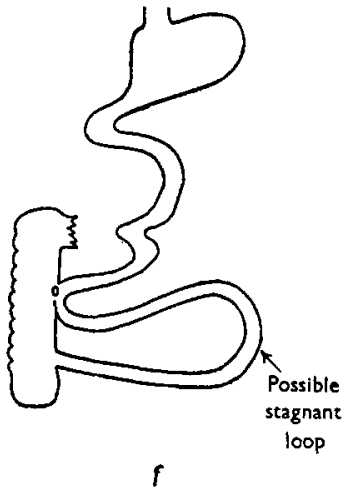

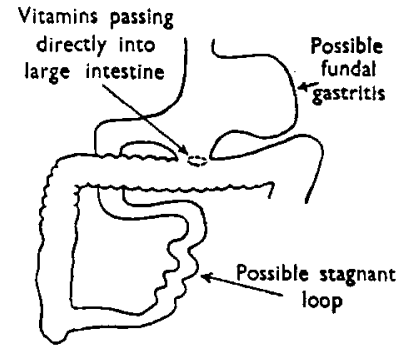

8

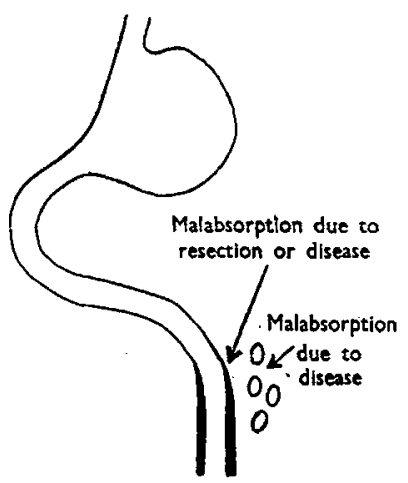

h

Fig. I. Commoner mechanisms of production of vitamin deficiency in alimentary diseases. (a) Total gastrectomy, extensive partial gastrectomy, neoplasm, or other conditions destroying fundal tissue of the stomach. (b) Partial gastrectomy with dilated loop. (c) Polya gastrectomy with long afferent loop. (d) Y-shaped anastomosis. (e) Gastroenterostomy. $(f)$ Jejuno-colic fistula. $(g)$ Gastro-colic fistula. (h) Disease of small intestine or mesenteric glands. 
confirming observations made 50 years previously by Cushing \& Livingood (1900) and by Hewetson (1904). The Australian workers, as a result of similar observations on patients undergoing gastrectomy operations, pour scorn on the view that vitamin B deficiencies after gastrectomy, in sprue or in nutritional megaloblastic anaemia, are due to bacteria invading the small intestine and depriving the host of vitamins. However, although these workers showed that in a number of patients undergoing operation for gastric or duodenal ulcer or for gastric carcinoma the flora present in the upper jejunum or lower ileum was not associated with a resident flora in the middle section of the small intestine, this does not to my mind entitle them to come to any conclusion about the mechanism in idiopathic steatorrhoea and related diseases which they did not investigate. Their view may be correct but it has yet to be proved.

\section{Mechanisms of production of vitamin deficiency in alimentary disorders}

The commoner mechanisms that may be involved are shown in Fig. $1 a-h$. So far as we know, destruction of the area of the stomach which produces intrinsic factor results in impaired absorption of vitamin $B_{12}$ alone as shown particularly in Fig. I $a$. After various operations for peptic ulcer a blind or stagnant loop of bowel may be produced. Our knowledge of what occurs in a stagnant area of bowel is inadequate, but it is possible that destruction of vitamins by bacteria, or the production of toxins or antimetabolites may take place. In an extension of the investigations summarized in Table $\mathrm{I}$ it has been possible to show that the organisms absorbed rather than destroyed cyanocobalamin. The other chief pathological mechanisms operating in the alimentary tract include continued rapid passage of the intestinal contents or, as a result of a fistula, the by-passing of a significant area of the small intestine. Malabsorption may be found where there is disease of the small intestine or of the mesenteric glands.

\section{Diseases and disorders associated with vitamin deficiency}

It would serve little purpose in making a list of such diseases to indicate in each instance exactly which vitamin deficiencies have been reported, particularly since the reports are usually based on clinical findings which may be completely misleading. In Table 2 there is given a list of the alimentary conditions in which deficiency of some or all of the vitamins has been reasonably well reported.

In some of the conditions listed in Table 2 the deficiency may be brought about or accentuated by dietetic restrictions or prolonged loss of appetite. Since nicotinicacid deficiency may give rise to nausea, vomiting and diarrhoea, and prolonged nausea, vomiting and diarrhoea may cause nicotinic-acid deficiency, it is obvious that, at least in this deficiency state, a vicious circle may be produced.

\section{Tests of bodily depletion and malabsorption of vitamins}

There is a lack of general agreement about the reliability of the various biochemical tests that have been used to measure bodily depletion of vitamins and their 
Table 2 Alimentary diseases and disorders in which vitamin deficiencies have been reported

Prolonged nausea or vomiting

Osteomyelitis of the jaw and other chronic oral lesions

Oesophageal strictures

Gastric tumours and gastric syphilis

Peptic ulcer (ascorbic-acid and nicotinic-acid deficiency)

Gastric neuroses

Partial gastrectomy with long afferent loop or dilated loop

Other causes of blind loops

Old gastroenterostomy or other short-circuiting operations

Gastro-jejuno-colic and other fistulas

Tuberculous enteritis

Tuberculous adenitis and reticuloses of the mesenteric glands

Regional jejunitis
Tumours of small intestine

Strictures of small intestine

Chylangioma mesenterica

Foreign body in abdominal cavity with intestinal anastomosis and blind cul-de-sac

Chronic dysenteries

Ulcerative colitis

Idiopathic steatorrhoea and tropical sprue

Coeliac disease

Intestinal parasites

Chronic intestinal obstruction

Overuse of cathartics, liquid paraffin, antibiotics

Rectal strictures and other chronic rectal disease (perhaps with associated overuse of cathartics)

Chronic pancreatic disease (deficiency of vita$\min \mathrm{A}$ and vitamin $\mathrm{K}$ )

absorption from the alimentary tract. In a case of idiopathic steatorrhoea, for example, the tests that might be considered include those listed in Table 3 .

Almost all tests of the types given in Table 3 have been criticized. In particular, measurement of the urinary excretion of a vitamin after it had been given in large dosage by mouth may give very misleading results since the output will depend upon many factors. These include the degree of absorption from the alimentary tract which may vary with the size of the dose, the extent of bodily depletion, the relative rates of urinary excretion and of uptake of the substance by the organs and tissues, the effects of renal disease, the rate and extent of metabolism of the substance in the body, and its uptake by any oedema fluid or effusion that may be present.

The differential urinary folic-acid excretion test. I have found a differential urinary folic-acid excretion test to be of great value in the diagnosis of the condition usually referred to as non-tropical sprue or idiopathic steatorrhoea and in the investigation of complex cases of megaloblastic anaemia. I want to deal at some length with the megaloblastic anaemias due to alimentary disturbances because they are in many ways easier to recognize than are other vitamin-deficiency states. The presence of megaloblasts in the bone marrow is a sign of deficiency of vitamin $B_{12}$, folic acid, or both. It is probable that this change is always an indication of advanced deficiency of these vitamins and possible that in pregnancy they may sometimes be seen not because of true deficiency but because of interference with folic-acid metabolism (Girdwood, 1953). Nevertheless, megaloblastic anaemia is a definite entity that can be readily recognized because megaloblasts are not found in normal marrow.

Biochemically, too, as I hope to show, there is something very definite to measure by a combination of the differential urinary folic-acid excretion test and a serumvitamin $\mathrm{B}_{12}$ measurement.

Usually, but not always, if a patient is depleted of folic acid his urinary output 
Table 3 List of some biochemical investigations of vitamin absorption and of 'bodily desaturation'

Vitamin

Vitamin A

Biotin

Thiamine

Riboflavin

Nicotinic acid

p-aminobenzoic acid

Pteroylglutamic acid

Cyanocobalamin in the presence of intrinsic factor

Ascorbic acid

Vitamin D

Vitamin E

Vitamin $\mathrm{K}$
Test

Blood vitamin A absorption tests

Urinary output after oral dose

Urinary output after injected dose; blood pyruvic acid and lactic acid after dextrose

Urinary output after oral dose

Urinary output after injected dose

Urinary output after oral or injected dose

Urinary output after complex 'saturation' test

Blood levels and urinary output after oral dose

Differential urinary folic-acid excretion test

Serum vitamin $\mathrm{B}_{12}$ level (Euglena gracilis)

(Lb. leichmannii)

Faecal excretion of orally administered cyanocobalamin labelled with radioactive cobalt

Urinary output of labelled cyanocobalamin after oral dose

Measurement of hepatic uptake of labelled cyanocobalamin

Urinary output after oral dose

Urinary output after injected dose

Measurement in blood or white cells and platelets

Serum alkaline phosphatase

Serum inorganic phosphorus

Serum calcium

Plasma-tocopherol tolerance tests

Determination of so-called prothrombin activity of plasma. This measures other deficiencies, including that of Factor VII

\author{
Reference \\ Yiengst \& Shock (1949); \\ Aron (1949) \\ Oppel (1948) \\ Williams, Mason, Power \& \\ Wilder (1943) \\ Friedman, Kmieciak, Keegan \\ \& Sheft (1948) \\ Axelrod, Spies \& Elvehjem \\ (I94I); Najjar \& Holt (I94I) \\ Najjar (I 944) \\ Ellinger \& Hardwick (1947) \\ Strauss, Lowell \& Finland \\ (I94I) \\ Girdwood (1953) \\ Mollin \& Ross (1953); Un- \\ glaub, Rosenthal \& Gold- \\ smith (I954); Girdwood \\ (1954) \\ Welch, Scharf, Heinle \& \\ Meacham (I 952) \\ Schilling (1953) \\ Glass (1954)
}

Harris \& Abbasy (1937)

Wright (1938)

Bessey, Lowry \& Brock (1947)

Klatskin \& Krehl (1950)

Quick (1940)

of folic acid is low after an injection of $5 \mathrm{mg}$ pteroylglutamic acid. If the patient is 'saturated' with folic acid by, say, $15 \mathrm{mg}$ injections of pteroylglutamic acid given daily for a week, and then the urinary excretion of folic acid after a 5 $\mathrm{mg}$ dose given orally is measured, it gives a very satisfactory measurement of the degree of absorption of folic acid from the alimentary tract.

The method is as follows:

(I) $5 \mathrm{mg}$ pteroylglutamic acid given by subcutaneous injection. All urine collected for $24 \mathrm{~h}$ and its folic acid content measured microbiologically (A).

(2) $5 \mathrm{mg}$ pterolyglutamic acid from the same batch given by mouth, in water. All urine collected for $24 \mathrm{~h}$ and its folic-acid content measured (B).

(3) The results may be expressed as percentages from the calculation $\frac{\mathrm{B}}{\mathrm{A}} \times \mathbf{1} 00$.

In normal persons the result is $70-140 \%$. In intestinal malabsorption the result may be very low indeed. For example, in one patient who was known to have idio- 
pathic steatorrhoea in adult life consequent upon coeliac disease in childhood and who had been receiving folic-acid therapy, the differential urinary folic-acid excretion test showed $0.22 \%$ absorption, while a fat balance test showed $87 \%$ absorption of fat. Another known case of idiopathic steatorrhoea with tetany but no diarrhoea had $95.8 \%$ fat absorption on a 7 -day fat balance test carried out in a metabolic ward. The differential urinary folic-acid excretion test showed only $4.9 \%$ absorption.

Megaloblastic anaemia need not be present. For example, I have had patients in whom the test showed marked impairment of folic-acid absorption and in whom the presenting features were: spontaneous fractures without anaemia (malabsorption of vitamin $\mathrm{D}$ and of calcium), a bleeding tendency and iron-deficiency anaemia (malabsorption of vitamin $\mathrm{K}$ and of iron) and iron-deficiency anaemia responding only to intravenous iron (malabsorption of iron); in one there were no symptoms or signs at the age of 2I years but there was a history of coeliac disease in childhood.

None of twenty-seven adult patients proved by other means to have intestinal malabsorption has had a negative folic-acid absorption test, although I am quite prepared to find that it sometimes occurs. None of seventy control patients showed abnormal results by this test.

It will be noticed that I prefer to use the term 'intestinal malabsorption' rather than idiopathic steatorrhoea, non-tropical sprue, the sprue syndrome or the malabsorption syndrome. There are several reasons for it. When a patient has malabsorption of folic acid and of iron with no diarrhoea and with normal fat absorption, the terms 'steatorrhoea' and 'sprue' are hardly applicable. The term 'syndrome' is usually used where there is a definite pattern of symptoms; in fact here the clinical features are polymorphous. Even the word 'idiopathic' is unsatisfactory-we have had patients believed at first to have idiopathic steatorrhoea who have been shown by laparotomy or post-mortem to have tuberculous adenitis of the mesenteric glands, regional jejunitis or tumours of the small bowel.

At the moment I cannot put forward results of absorption tests for other vitamins, but investigations along similar lines in relation to other vitamins are proceeding.

Recently with the assistance of Dr Malcolm Low, I have done preliminary experiments to extend this folic-acid excretion test by adding the oral dose of pteroylglutamic acid to $50 \mathrm{~g}$ glucose in solution and doing a blood-sugar curve and serum folic-acid test over a period of $4 \mathrm{~h}$. This procedure enables us to do two absorption tests at once. The peaks usually come at different times, the folic-acid peak being from $\mathrm{I}_{2} \frac{1}{2}$ to $3 \mathrm{~h}$ after the oral dosing. So far, in three cases of intestinal malabsorption treated for several years, the glucose-tolerance curves were flat and the rises of serum folic acid at $3 \mathrm{~h}$ were 7,8 and $20 \mathrm{~m} \mu \mathrm{g} / \mathrm{ml}$. In thirteen controls, including three cases of megaloblastic anaemia of pregnancy and one who had steatorrhoea after partial gastrectomy, the blood-sugar curves showed no evidence of malabsorption and the serum folic-acid rise at $3 \mathrm{~h}$ ranged from 90 to $235 \mathrm{~m} \mu \mathrm{g} / \mathrm{ml}$.

Method of vitamin therapy. From the therapeutic point of view, it would seem desirable in intestinal malabsorptive diseases to supplement orally administered pteroylglutamic-acid therapy with occasional injections of the substance. The same 


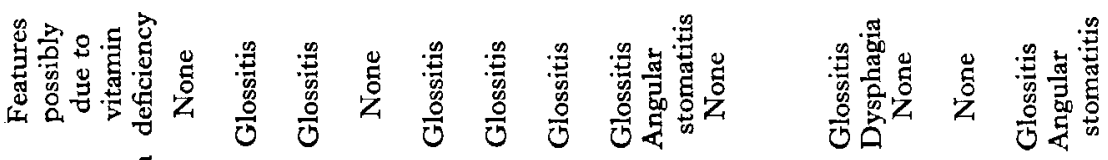

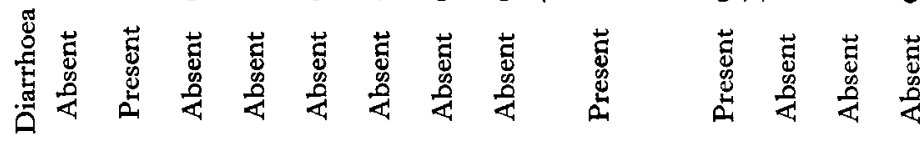

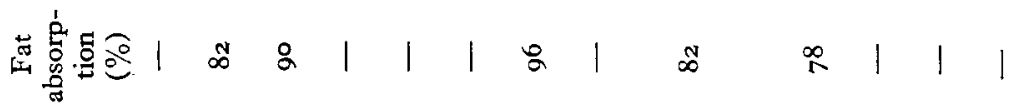

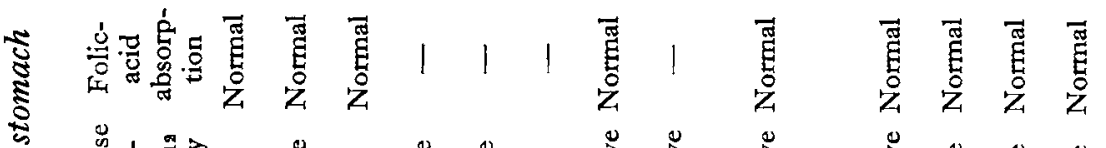

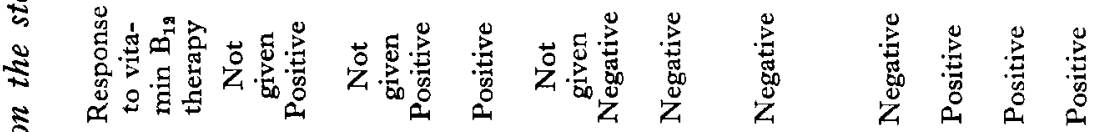

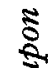
离

$\frac{8}{8}$

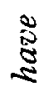

욜

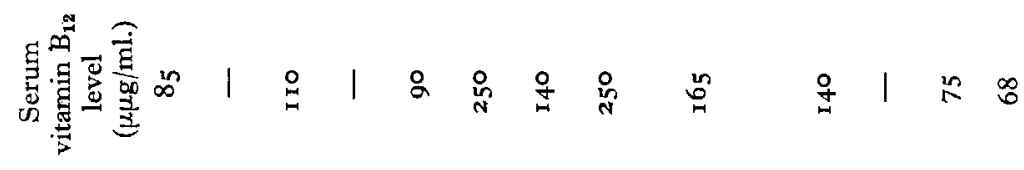
है

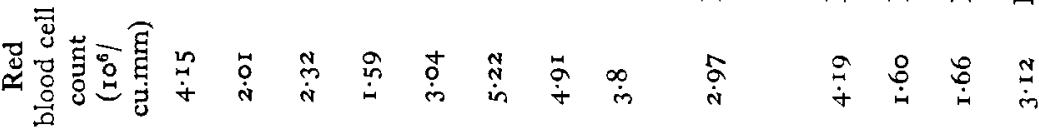

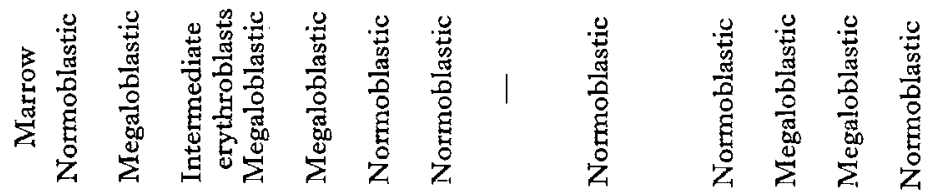

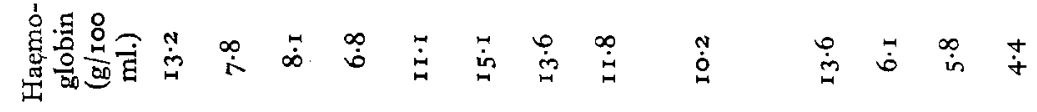

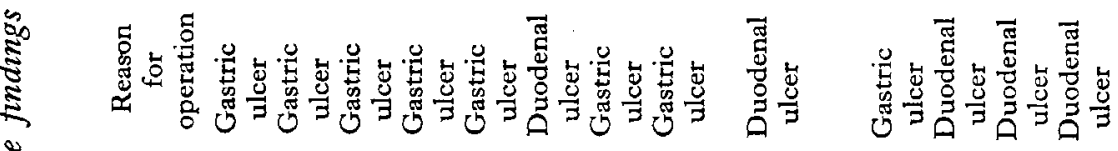

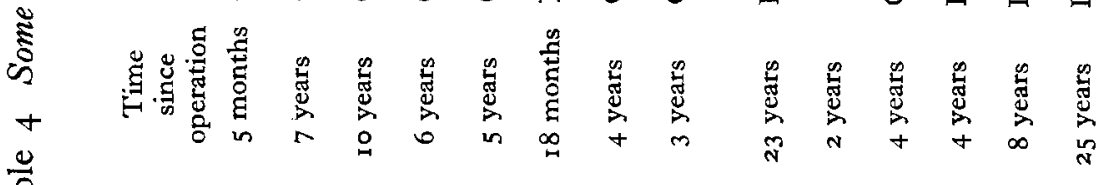
$\frac{0}{\frac{0}{0}}$

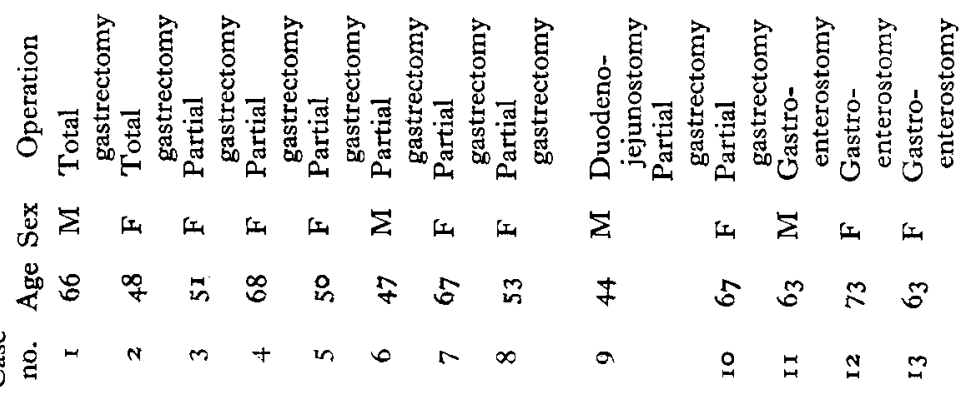


is true of other vitamins. My experience, like that of Badenoch \& Fourman (1954), has been that large doses of vitamin D are required, and recently Boscott $\&$ Cooke (1954) have suggested that there is an abnormal utilization or requirement of ascorbic acid. I am not one of those who believe that almost every disease known to man should be treated with vitamin E, but I wonder whether we should not investigate further the possibility of vitamin $\mathrm{E}$ deficiency being of importance in malabsorptive diseases. Deficiency of vitamins of the $B$ complex are frequently seen, and vitamin $B_{12}$ deficiency occurs occasionally.

\section{Vitamin deficiencies after operations upon the stomach}

Although steatorrhoea is not uncommon after gastrectomy or gastroenterostomy operations, clinical evidence of vitamin deficiencies is not frequently found. This is shown in a paper by Blake \& Rechnitzer (1953) from the Department of Medicine of the University of Edinburgh, dealing with 179 patients.

Again, however, the vitamin deficiency that becomes easily obvious and that can be measured fairly exactly by biochemical methods is one that gives megaloblastic anaemia. This time, however, although steatorrhoea may be present simultaneously, the deficiency in my experience has been of vitamin $\mathrm{B}_{12}$ and not of folic acid.

The serum vitamin $\mathrm{B}_{12}$ level may be measured microbiologically with $L b$. leichmannii as the test organism. The normal range by this method is $130-600 \mu \mu \mathrm{g} / \mathrm{ml}$. (Girdwood, 1954). In Table 4 there are given the findings in a series of patients referred after gastric operations because they were believed to be anaemic. They are not included in Blake \& Rechnitzer's paper. A few were seen before vitamin $B_{12}$ assays were possible.

It will be seen from Table 4 that megaloblastic anaemia after such operations is associated with a low serum level of vitamin $B_{12}$ and responds to cyanocobalamin therapy. The lowering of the serum level of vitamin $B_{12}$ may precede the appearance of megaloblasts in the marrow. Indeed case 3 has been maintained on pteroylglutamic-acid therapy for 18 months without further haematological relapse or neurological complications, and her vitamin $\mathrm{B}_{12}$ level is now $50 \mu \mu \mathrm{g} / \mathrm{ml}$. In cases 2,7 and 8 the glossitis has not responded to therapy with multivitamin tablets, cyanocobalamin or pteroylglutamic acid. In cases 8 and 9 the anaemia has not responded to these measures, but the latter patient had a dilated stagnant loop. In most instances loss of intrinsic factor with resultant vitamin $B_{12}$ deficiency appears to be the primary cause of the anaemia, but other factors as shown in Fig. $\mathrm{I} a-h$ may sometimes be involved.

\section{REFERENCES}

Aron, H. C. S. (1949). Amer. F. Dis. Child. 77, 763.

Axelrod, A. E., Spies, T. D. \& Elvehjem, C. A. (r94I). F. clin. Invest. 20, 229.

Badenoch, J. \& Fourman, P. (1954). Quart. F. Med. 23, 165.

Bean, W. B. \& Spies, T. D. (1940). F. Amer. med. Ass. Ir5, 1078.

Bessey, O. A., Lowry, O. H. \& Brock, M. J. (1947). F. biol. Chem. 168, 197.

Blake, J. \& Rechnitzer, P. A. (1953). Quart. F. Med. 22, 419.

Boscott, R. J. \& Cooke, W. T. (1954). Quart. F. Med. 23, 307.

Burkholder, P. R. (1952). Arch. Biochem. Biophys. 39, 322. 
Cregan, J., Dunlop, E. E. \& Hayward, N. J. (1953). Brit. med. F. ii, r248.

Cregan, J. \& Hayward, N. J. (1953). Brit. med. F. i, 1356.

Cushing, H. \& Livingood, L. E. (1900). Fohns Hopk. Hosp. Rep. 9, 543.

Ellinger, P. \& Hardwick, S. W. (1947). Brit. med. F. i, 672.

Friedman, T. E., Kmieciak, T. C., Keegan, P. K. \& Sheft, B. B. (1948). Gastroenterology, II, 101.

Girdwood, R. H. (1953). Lancet, 265, 53 .

Girdwood, R. H. (1954). Brit. med. F. ii, 954.

Glass, G. B. J. (1954). Int. Congr. Haemat. v. Paris. (In the Press.)

Harris, L. J. \& Abbasy, M. A. (1937). Lancet, 233, I429.

Hewetson, J. T. (1904). Brit. med.F. ii, 1457.

Klatskin, G. \& Krehl, W. A. (1950). F. clin. Invest. 29, 1528.

Lascelles, J. \& Woods, D. D. (1952). Brit. F. exp. Path. 33, 288.

Mollin, D. L. \& Ross, G. I. M. (1953). Brit. med. F. ii, 640.

Najjar, V. A. (1944). Fohns Hopk. Hosp. Bull. 74, 392.

Najjar, V. A. \& Holt, L. E. Jr. (1941). Fohns Hopk. Hosp. Bull. 69, 476.

Oppel, T. W. (1948). Amer. F. med. Sci. 215, 76.

Quick, A. J. (1940). Amer. F. clin. Path. 10, 222.

Schilling, R. F. (1953). F. Lab. clin. Med. 42, 860.

Strauss, E., Lowell, F. C. \& Finland, M. (194I). F. clin. Invest. 20, 189.

Unglaub, W. C., Rosenthal, H. L. \& Goldsmith, G. R. (1954). F. Lab. clin. Med. 43, I43.

Welch, A. D., Scharf, V., Heinle, R. W. \& Meacham, G. C. (1952). Fed. Proc. 11, 308.

Williams, R. D., Mason, H. L., Power, M. H. \& Wilder, R. M. (1943). Arch. intern. Med. 71, 38.

Wright, I. S. (1938). Ann. intern. Med. 12, 5 I6.

Yiengst, M. J. \& Shock, N. W. (r949). Fed. Proc. 8, 173.

\section{Mineral Metabolism in Alimentary Disease}

\section{By D. A. K. Black, Department of Medicine, The Royal Infirmary, Manchester}

Diseases of the alimentary tract affect mineral metabolism in two main ways-by deprivation or malabsorption of dietary minerals, and by loss in vomitus or faeces of the minerals contained in alimentary-tract secretions. The interference with absorption which must underlie both these mechanisms may be mechanical, as in pyloric stenosis; or may be functional, as in idiopathic steatorrhoea. The two mechanisms may indeed both be operative, as in intestinal obstruction, where food intake is valueless and at the same time large amounts of minerals are lost by vomiting and by continuous aspiration of alimentary secretions. In general, chronic alimentary disease causes mineral malnutrition mainly by deprivation and malabsorption of food minerals, whereas in acute catastrophes the effects of loss of alimentary secretions predominate. Since the mineral composition of alimentary secretions is much more akin to that of extracellular fluid than to that of cellular and skeletal tissue, the acute catastrophes cause the syndrome of dehydration, whereas chronic illness leads to a bewildering variety of mineral disturbances involving intracellular ions such as potassium and phosphate, and bone minerals such as calcium and phosphorus. Again, the distinction is not absolute, for potassium depletion is demonstrable both in acute and chronic alimentary-tract disease. Besides straightforward deprivation, malabsorption, or loss of minerals, alimentary-tract disease can influence mineral metabolism indirectly by way of general nutritional disturbance, as in the sequence : anorexia $\rightarrow$ deficient intake of calories and proteins $\rightarrow$ hypoproteinaemia $\rightarrow$ low plasma volume $\rightarrow$ renal retention of salt and water $\rightarrow$ oedema. 